\title{
DA DISCIPLINA AO CONTROLE: TECNOLOGIAS DE SEGURANÇA, POPULAÇÃO, E MODOS DE SUBJETIVAÇÃO EM FOUCAULT
}

\author{
Luiz Alberto Moreira Martins
}

Partindo do pressuposto de que os processos de subjetivação são efeitos de tecnologias e de práticas de poder, em constante transformação, procuramos investigar a emergência e a instauração das tecnologias de segurança, que caracterizam a sociedade de controle. A partir da perspectiva da analítica do poder, investigamos as transformaçôes do poder soberano e a instauração dos principais mecanismos da sociedade disciplinar. Analisamos ainda a emergência da biopolítica e dos dispositivos de segurança articulados com a noção de população e a economia política liberal.

\section{BANCA:}

Carlos Augusto Peixoto Junior (Orientador)

Guilherme Castelo Branco

Paulo Roberto Gibaldi Vaz

Data de defesa: 9/11/2007 